\title{
Characterization of Rabbit Mesenchymal Cell Attachment on Calcium Phosphate Surface
}

\author{
Vita Zalite ${ }^{1}$, Marina Sokolova ${ }^{2}$, Dmitrijs Jakovlevs ${ }^{3}$, Karlis Rozenbergs $^{4}$, Liga Berzina-Cimdina ${ }^{5}$, \\ ${ }^{1-3,5}$ Riga Technical University, ${ }^{4}$ University of Latvia
}

\begin{abstract}
In the current study, the effect of three different treated surfaces of hydroxyapatite and $\beta$-tricalcium phosphate on mesenchymal cell attachment has been investigated. Calcium phosphate powders have been synthesized, uniaxially pressed, polished and sintered. Mesenchymal cells have been seeded onto unpolished, polished and polished-thermally etched ceramic samples. The ceramic samples have been characterized by XRD, FTIR and SEM. Results have shown that the best cell attachment and morphology are on the unpolished surface indicating that relatively rough surface is better for cell application.
\end{abstract}

Keywords - Hydroxyapatite, implant surface, mesenchymal cells, $\beta$-tricalcium phosphate.

\section{INTRODUCTION}

Calcium phosphate $(\mathrm{CaP})$ bioceramics, such as hydroxyapatite (Hap) and $\beta$-tricalcium phosphate ( $\beta$-TCP), are important biomaterials for dental, craniofacial and orthopedic repairs due to their similarity to bone mineral component and bone bonding ability to form a functional interface. Many scientific studies are devoted to the investigation of coatings and their surface of metallic implants [1-4]. The most popular materials applied as metal implant coatings are calcium phosphates due to their ability to form an apatite layer indicating bioactive and osteoconductive properties [5-6]. The characteristics of surface of any biomaterial are essential for protein adsorption after a surgical procedure and subsequently cell attachment and proliferation. In fact, there are many methods for surface treatment and modification. The ion implantation [7], powder abrasive treatment [8], laser irradiation [9], plasma spraying [10] and modification with nanoparticles [11] are named as the most popular approaches.

The bone marrow stromal cells or mesenchymal stem cells (MSCs) have been shown to differentiate into bone, as well as cartilage and fat cells [12], which makes them ideal candidates for developing bone tissue-engineered constructs. It is well known that $\mathrm{CaP}$ materials promote MSCs differentiation down the osteogenic lineage [13-15] and that surface topography and particle size have an effect on cell proliferation and differentiation [16-18].

Hap and $\beta$-TCP ceramics are popular scaffold materials in tissue engineering for stem cell seeding. CaP ceramics, seeded with stem cells, are a promising approach for better bone tissue ingrowth. Increasing cell seeding efficiency in a tissue engineering construct, it is possible to enhance a cellular activity and tissue formation as well.

In the current study, different treated Hap and $\beta$-TCP ceramic surfaces were used to investigate rabbit mesenchymal stem cell attachment. Three various, but simple surface treatment technologies (sintering, polishing and polishing-thermally etching) were used. Up to date there is no study, regarding the effects of Hap and $\beta$-TCP surface morphology, treated by polishing, sintering and polishing-thermally etching, on cellular response. The aim of the research is to identify morphology of the implant surfaces, which could enhance cell attachment. The understanding of impact of surface properties on cells, proteins and tissue response could give knowledge for development of dental and orthopaedic implants.

\section{MATERIALS AND METHODS}

\section{A. Preparation of Calcium Phosphates Powders}

Calcium phosphate powders were prepared by a wet chemical precipitation method using calcium oxide (Fluka, Germany) and ortophosphoric acid (Sigma-Aldrich, Germany) as raw materials. The process can be described by the following reactions:

$$
\begin{gathered}
\mathrm{CaO}+\mathrm{H}_{2} \mathrm{O} \rightarrow \mathrm{Ca}(\mathrm{OH})_{2} \\
10 \mathrm{Ca}(\mathrm{OH})_{2}+6 \mathrm{H}_{3} \mathrm{PO}_{4} \rightarrow \mathrm{Ca}_{10}\left(\mathrm{PO}_{4}\right)_{6}(\mathrm{OH})_{2}+18 \mathrm{H}_{2} \mathrm{O}
\end{gathered}
$$

This method has been characterized by a simple process, low cost, easy application in industrial production and water is the only by-product. The method is found to be highly dependent on the selected technological parameters, such as reagents, impurity content, concentration of reagents, mixing conditions, $\mathrm{pH}$ and temperature. The raw material was calcined at $1000{ }^{\circ} \mathrm{C}$ for $1 \mathrm{~h}$ to obtain pure $\mathrm{CaO}$, then distilled water was added to gain $\mathrm{Ca}(\mathrm{OH})_{2}$ suspension with concentration $0.15 \mathrm{M}$ (1). The precipitation reaction was carried out at $45^{\circ} \mathrm{C}$ for Hap or ambient temperature for $\beta$-TCP production. The $2 \mathrm{M}$ phosphoric acid solution was added slowly into the calcium hydroxide solution (2). The mixture was stirred for $1 \mathrm{~h}$, after the end $\mathrm{pH}$ value ( 8.7 for Hap or 6.0 for $\beta$-TCP) was obtained, then aged for $20 \mathrm{~h}$ at room temperature. Lower synthesis temperature and acidic $\mathrm{pH}$ values promote formation of $\beta$-TCP phase, but slightly alkaline $\mathrm{pH}$ and higher temperature promote formation of Hap phase. Varying these parameters, it is possible to obtain a calcium phosphate product with diverse phase composition. Thereafter filtered precipitates were dried at $105^{\circ} \mathrm{C}$ for $24 \mathrm{~h}$. The as-synthesized powder was heat treaded at $1100{ }^{\circ} \mathrm{C}$ for $1 \mathrm{~h}$ to establish phase and chemical purity.

\section{B. Examination of Calcium Phosphate Powders}

The phase composition and chemical purity of Hap and $\beta$-TCP powders were investigated using X-ray diffractometry (XRD) and Fourier transform infrared spectroscopy (FTIR). 
XRD analysis was carried out with PANalytical X'Pert Pro, $\mathrm{Cu}$ $\mathrm{K} \alpha 1,40 \mathrm{kV}, 30 \mathrm{~mA}$. FTIR analysis was performed with Varian Scimitar 800 in the wavenumber range of $4000-400 \mathrm{~cm}^{-1}$.

\section{Preparation of Ceramic Samples}

Obtained as-synthesized powders were uniaxially pressed into pellets $(\mathrm{d}=10 \mathrm{~mm}, \mathrm{H}=3 \mathrm{~mm})$. All samples were sintered at $1100{ }^{\circ} \mathrm{C}$ for 1 hour. Unpolished, polished and thermally etched samples were used for investigation of stem cell attachment. Polished ceramic samples were prepared by polishing with $6 \mu \mathrm{m}, 1 \mu \mathrm{m}, 0,25 \mu \mathrm{m}$ diamond paste and cleaned in the ultrasonic bath using deionized water for $1 \mathrm{~min}$. Thermal etching was carried out at $1000{ }^{\circ} \mathrm{C}$ for $4 \mathrm{~min}$, to reveal the grain boundaries of matrix grains after polishing. Hap and $\beta$-TCP pellets were steam sterilized in an autoclave at $121^{\circ} \mathrm{C}$ for $30 \mathrm{~min}$.

\section{Examination of Ceramic Samples}

For the scanning electron microscopy (SEM) samples with a thin layer of gold was prepared using gold sputter coater (Emitech K550X, QUORUM TECHNOLOGIES Company) with a sputtering rate of $7 \mathrm{~nm} / \mathrm{min}$ applying $25 \mathrm{~mA}$ current. The total gold coating thickness was approximately $14 \mathrm{~nm}$. Micrographs were obtained using MirallLMU SchottkyEmission electron gun SEM (TESCAN Company) at an accelerating voltage of $15 \mathrm{kV}$ and magnification of 3,000 $\mathrm{x}$. The double detector system was used.

Cells were fixed in $2.5 \%$ glutaraldehyde and dehydrated with increasing concentrations of acetone $(50 \%, 60 \%, 70 \%$, $80 \%, 90 \%$ ) for 10 minutes each concentration, then samples were dried in critical point dryer (Polaron, OM-E3000, QUORUM TECHNOLOGIES Company) for 1 hour in $\mathrm{CO}_{2}$ medium.

The density and porosity of the samples were determined using the Archimedes' method.

\section{E. Mesenchymal Cell Isolation and Culture}

The rabbit mesenchymal cells were isolated using enzymatic digestion with collagenase type XI (Sigma) and seeded for expansion in Dulbecco's Modified Eagle Medium $(\mathrm{DMEM}) / 10 \%$ fetal bovine serum (FBS) in standard culture conditions $\left(37{ }^{\circ} \mathrm{C}, 95 \%\right.$ relative humidity, and $\left.5 \% \mathrm{CO}_{2}\right)$. Cells were passaged by trypsinizing $(0.05 \%$ trypsin/ ethylenediaminetetraacetic acid (EDTA)) and subcultured at a density of 4000 cells $/ \mathrm{cm}^{2}-5000$ cells $/ \mathrm{cm}^{2}$. For all experiments cells between the third and fifth passage were used. On average 70000 cells were seeded onto the Hap and $\beta$-TCP ceramic pellets one day prior further use.

\section{RESULTS AND DISCUSSION}

The X-ray diffraction patterns of the synthetic calcium phosphate powders show the phase composition after thermal treatment in $1100{ }^{\circ} \mathrm{C}$ for 1 hour (Fig. 1). The sharp peaks indicate well crystalline calcium phosphate powders. In Fig. 1 A, HAp phase is represented, and in Fig. $1 \mathrm{~B}, \beta$-TCP phase can be seen. All maximums, which are shown in the diffractogramms, correspond to pure HAp and pure $\beta$-TCP phases. The crystalline phases detected in the patterns were identified according to standard patterns from the ICDD - PDF database (No. 9-432 for HAp and No. 55-898 for $\beta$-TCP).
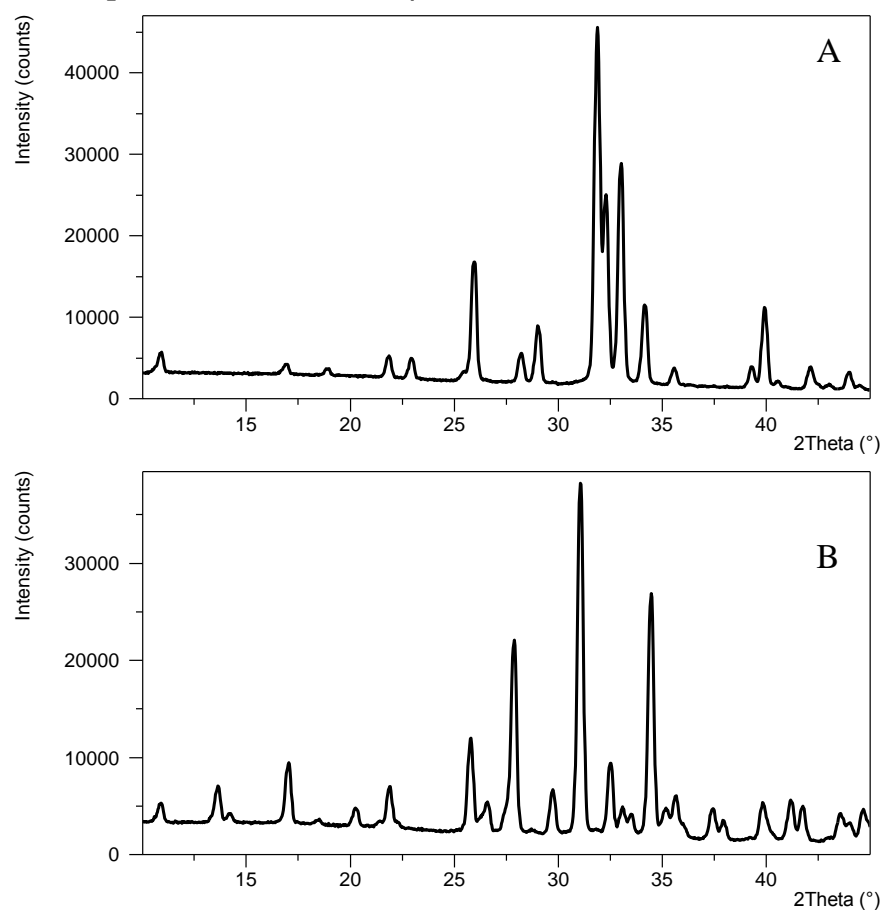

Fig. 1. X-ray diffractometry patterns: A - HAp phase, $B-\beta$-TCP phase.

FTIR analysis shows the characteristic vibrations of chemical bands of HAp (Fig. 2. A) and $\beta$-TCP (Fig. 2. B).
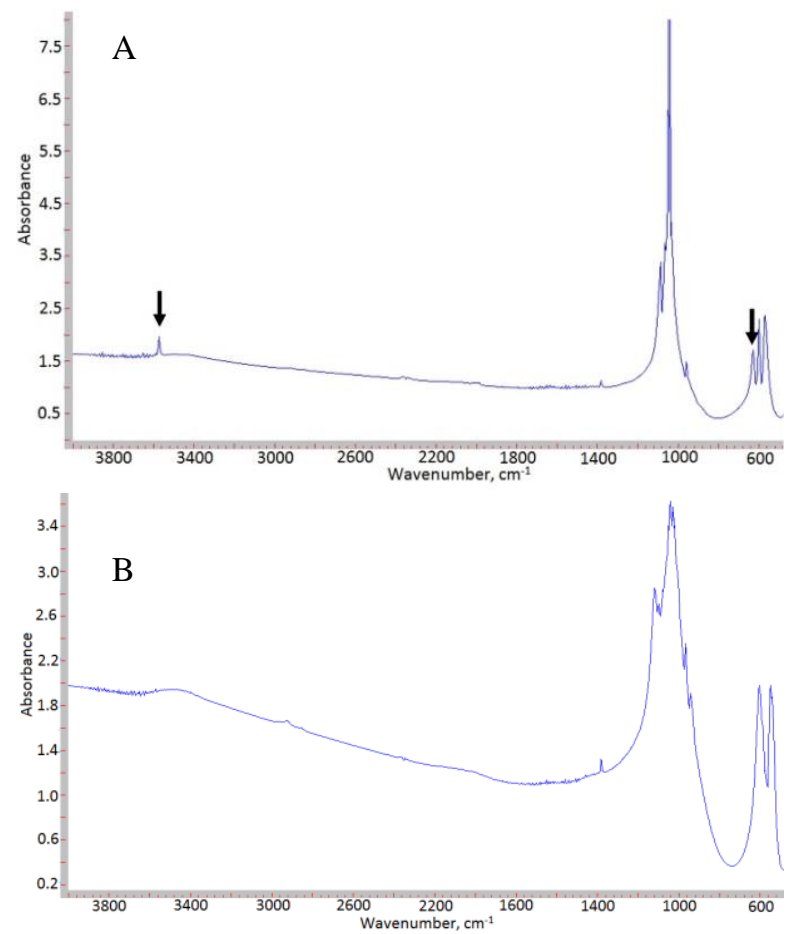

Fig. 2. FTIR spectra: A - HAp, B - $\beta$-TCP

FTIR spectra show vibration modes of $\mathrm{PO}_{4}{ }^{-3}$ ions in the wavenumber range of $550 \mathrm{~cm}^{-1}-600 \mathrm{~cm}^{-1}, 962 \mathrm{~cm}^{-1}, 1020 \mathrm{~cm}^{-1}-$ $1120 \mathrm{~cm}^{-1}$, those are typical for HAp and $\beta$-TCP. HAp phase can be confirmed with peaks indicating $\mathrm{OH}^{-}$functional groups located at wavenumbers of $640 \mathrm{~cm}^{-1}$ and $3571 \mathrm{~cm}^{-1}$, denoted with 
arrows (Fig. 2 A). On the contrary, there is no evidence of $\mathrm{OH}^{-}$ groups in Fig. 2. B that proves the existence of pure $\beta$-TCP
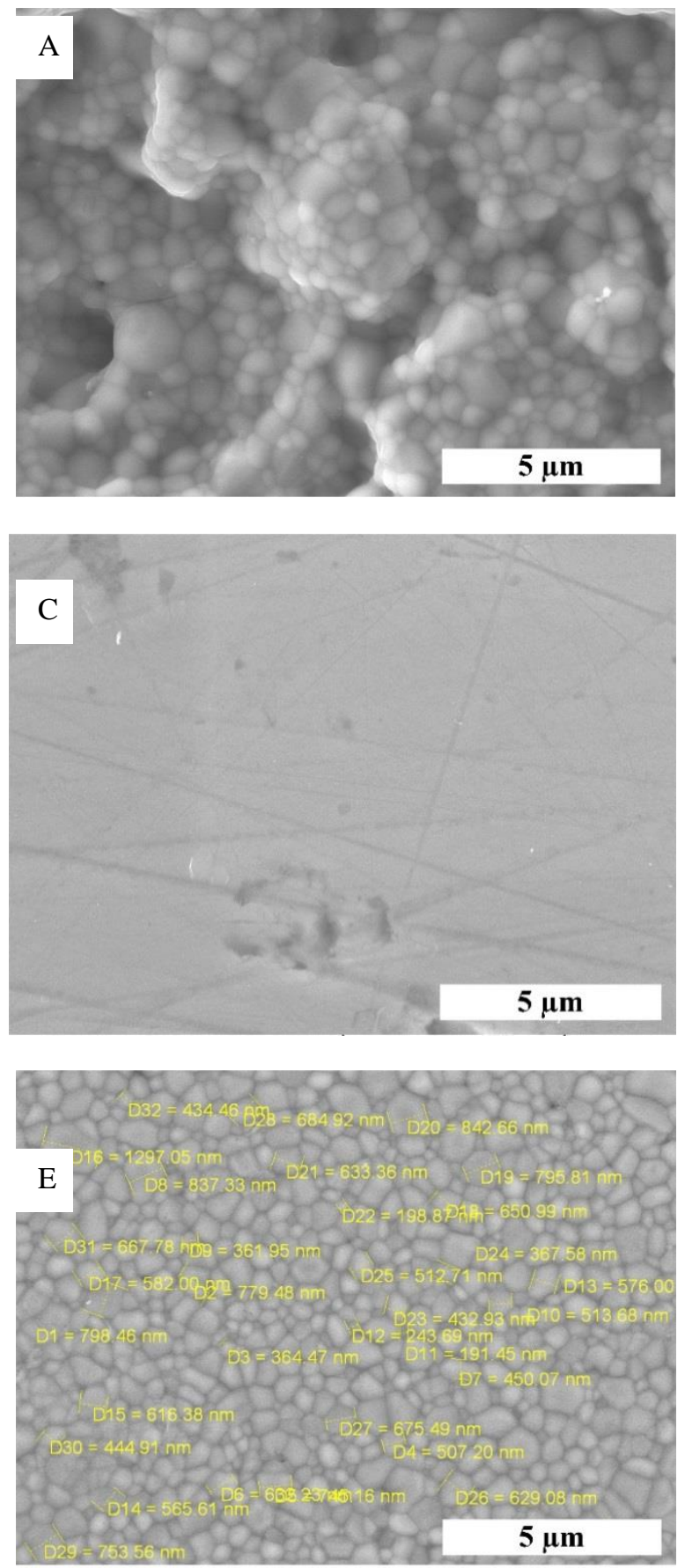

phase; in addition, the broadening of stretching mode of $\mathrm{PO}_{4}{ }^{3-}$ group is a typical indication of formation of $\beta$-TCP.
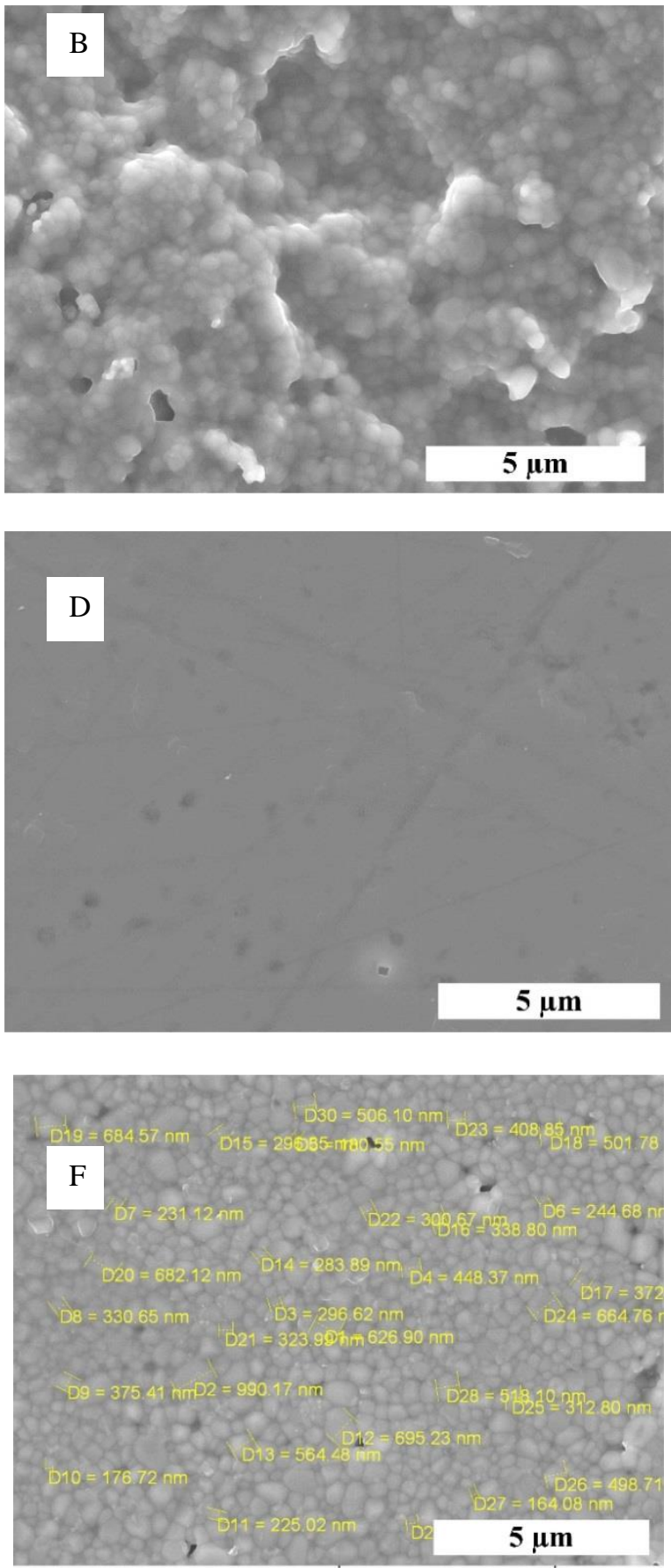

Fig. 3. SEM micrographs: A - unpolished $\beta$-TCP, B - unpolished HAp, C - polished $\beta$-TCP, D - polished HAp, E - polished and thermally etched $\beta$-TCP, $\mathrm{F}$ - polished and thermally etched HAp.

The microstructural comparison of the prepared samples is presented in Fig. 3. Sintered and unpolished surfaces of $\beta$-TCP and HAp have similar morphology. It is rounded and relatively rough with clearly visible grains, see Fig. 3 A and B micrographs. SEM images C and D demonstrate polished surfaces of both ceramics. There are no significant differences between $\beta$-TCP and HAp surfaces. There are some grooves resulting from polishing procedure. However, the microstructural evaluation of polished and then thermally etched samples (Fig. 3. E and F) reveals the structure of grains. Results indicate that $\beta$-TCP ceramic (Fig. 3. E) has larger grains $\left(D_{\mathrm{Av}}=587 \mathrm{~nm}\right.$ ) compared to HAp ceramic $\left(D_{\mathrm{Av}}=566 \mathrm{~nm}\right)$ (Fig. 3. F), which is according to literature [19]. In $\mathrm{E}$ and $\mathrm{F}$ images, it can be seen that $\beta$-TCP microstructure is denser, while HAp microstructure has some micropores. The density of $\beta$-TCP and HAp ceramics is $2.6 \mathrm{~g} / \mathrm{cm}^{3}$ and $2.2 \mathrm{~g} / \mathrm{cm}^{3}$, respectively. Measurement and calculation of porosity indicates that total porosity is in range from $15 \%$ to $17 \%$ for $\beta$-TCP and $27 \%$ to $31 \%$ for HAp. The density and porosity differences could be explained due to 
sintering temperature. $\beta$-TCP has a lower sintering temperature than HAp that agrees with the studies of other authors [20].

TABLE 1

POROSITY AND DENSITY OF $\beta$-TCP AND HAP SAMPLES

\begin{tabular}{lllll} 
& Density $\left[\mathrm{g} / \mathrm{cm}^{3}\right]$ & $\mathrm{P}_{\text {open }}[\%]$ & $\mathrm{P}_{\text {closed }}[\%]$ & $\mathrm{P}_{\text {total }}[\%]$ \\
\hline$\beta$-TCP- $n p$ & $2.60 \pm 0.01$ & $14.2 \pm 0.4$ & $3.3 \pm 0.2$ & $17.5 \pm 0.4$ \\
\hline$\beta$-TCP- $p$ & $2.64 \pm 0.04$ & $10.1 \pm 2.2$ & $4.9 \pm 1.0$ & $14.9 \pm 1.3$ \\
\hline$\beta$-TCP- $t e$ & $2.61 \pm 0.01$ & $13.5 \pm 0.5$ & $2.9 \pm 0.2$ & $16.4 \pm 0.4$ \\
\hline \hline HAp- $n p$ & $2.23 \pm 0.07$ & $26.9 \pm 2.2$ & $4.0 \pm 0.5$ & $31.1 \pm 2.1$ \\
\hline HAp- $p$ & $2.30 \pm 0.02$ & $22.3 \pm 0.3$ & $4.6 \pm 0.2$ & $26.9 \pm 0.1$ \\
\hline HAp- $t e$ & $2.25 \pm 0.01$ & $24.2 \pm 0.6$ & $5.0 \pm 0.7$ & $29.2 \pm 0.2$ \\
\hline
\end{tabular}

Abbreviations: $n p$ - non-polished, $p$ - polished, $t e$ - thermally etched

All samples seeded with mesenchymal cells were examined 24 hours after cell seeding on the biomaterial surface. In all cases (Fig. 4.), morphology of cells differs. On the unpolished
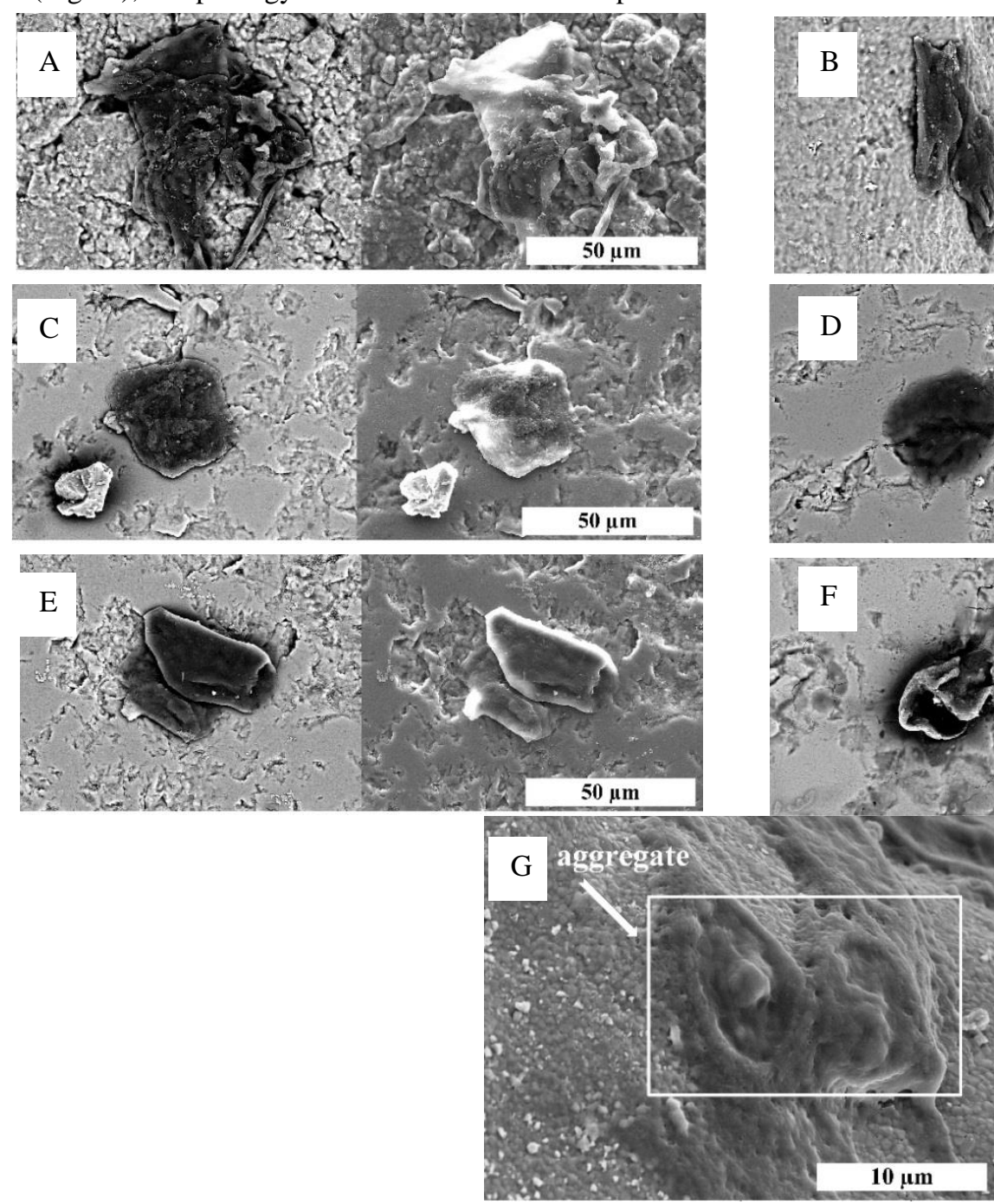

Fig. 4. SEM images of ceramic samples with mesenchymal stem cells: A - unpolished $\beta$-TCP, B - unpolished HAp, C - polished $\beta$-TCP, D - polished HAp,

E - polished and thermally etched $\beta$-TCP, F - polished and thermally etched Hap, G - aggregate of cells on unpolished Hap. surface, cells exhibit an indistinct and flattened shape, while on the polished surface cells have a more rounded shape. Considering cell shape, thermally-etched samples showed a relatively worse cell vitality, compared to the cells on the unpolished and polished surfaces. SEM analysis revealed a relatively better mesenchymal cell adhesion on the hydroxyapatite samples than $\beta$-tricalcium phosphate samples. In fact, aggregates of cells were observed, see Fig. $3 \mathrm{G}$. Roohani-Esfahani et al. have investigated the effect of material surface characteristics on the mesenchymal cell proliferation and differentiation. They observed that flatter topographies enhance cell proliferation while rougher, micro-scale topographies enhance osteogenic differentiation of cells [12]. Although we could not study proliferation and differentiation as cells were observed already after 24 hours, in accordance with the reviewed authors' group, it could be concluded that the rough surface of calcium phosphates was more favourable for cells in comparison with smoother surfaces.
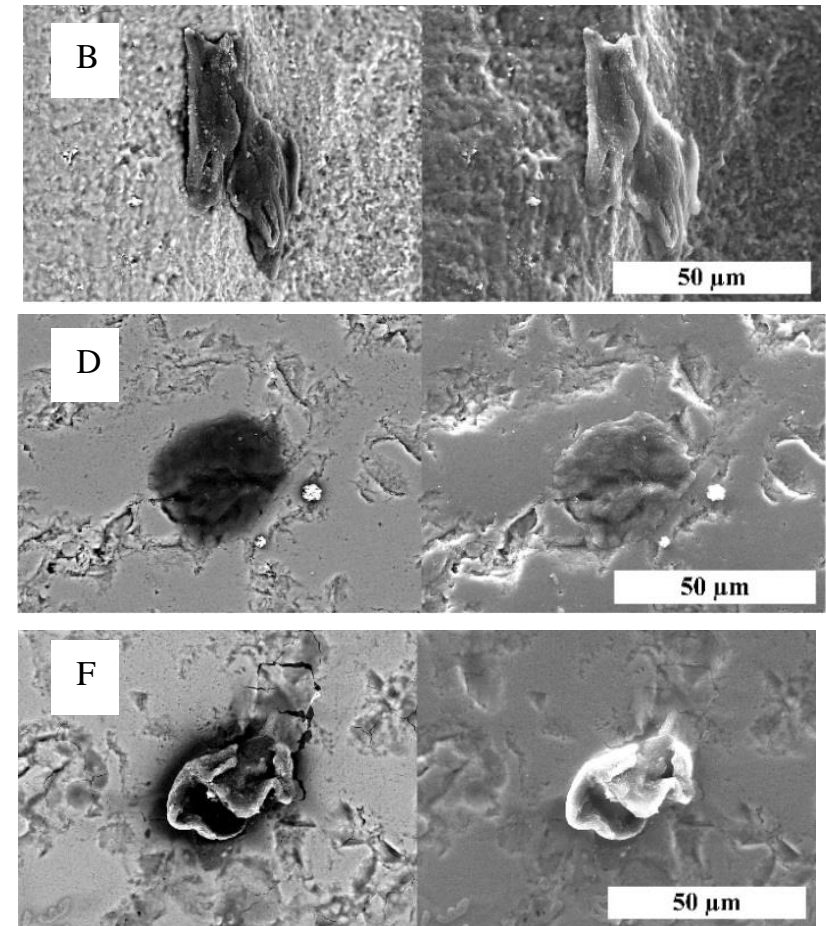

$50 \mu \mathrm{m}$ 


\section{CONCLUSIONS}

As the cells are living organisms, they should connect to each other to have a possibility of forming a new tissue [21]. Rounded cell morphology indicates that probably cells do not aim to connect to each other.

The microstructural effect of hydroxyapatite and $\beta$-tricalcium phosphate on rabbit mesenchymal stem cells has been sudied. SEM investigation revealed the differences between a surface microstructure of HAp and $\beta$-TCP, which are mainly attributed to grain size, density and porosity. $\beta$-TCP has larger grains and denser microstructure as HAp at the same thermal and surface treatment conditions.

The current study revealed that material surface features could influence attachment and morphology of cells. The smooth surfaces, in this case, polished and polished-thermally etched, were not favourable for cell attachment, while an unpolished surface was more suitable for cell application. There were no scientific differences discovered between droxyapatite and $\beta$-tricalcium phosphate phases regarding mesenchymal cell attachment and morphology, but it is an important factor that needs to be taken into account.

The future work will be devoted not only to surface topography investigation, but also to chemical factors of biomaterial that could influence cell behavior on the calcium phosphate scaffolds.

\section{ACKNOWLEDGMENTS}

The present research has been supported by the National Research Program of Latvia in Material Sciences No. 2 "Development of Novel Multifunctional Materials, Signal Processing and Information Technologies for Competitive Knowledge-Based Products - IMIS" project No. 4 "Novel Materials and Technologies for Implantation and Evaluation of Biological Tissues".

\section{REFERENCES}

[1] Lopez-Estebana, S., Saiza, E., Fujinob, S., et al. Bioactive Glass Coatings for Orthopedic Metallic Implants. Journal of the European Ceramic Society, 2003, vol. 23, pp. 2921-2930. http://dx.doi.org/10.1016/S0955-2219(03)00303-0

[2] Ungersbock, A., Rahn, B. Methods to Characterize the Surface Roughness of Metallic Implants. Journal of Materials. Materials in Medicine, 1994, vol. 5, pp. 434-440. http://dx.doi.org/10.1007/BF00058979

[3] Liua, X, Chub, P.K., Ding, Ch. Surface Modification of Titanium, Titanium Alloys and Related Materials for Biomedical Applications. Materials Science and Engineering, 2004, R 47, pp. 49-121.

[4] Liu, D., Savino, K., Yates, M.Z. Coating of Hydroxyapatite Films on Metal Substrates by Seeded Hydrothermal Deposition. Surface \& Coatings Technology, 2011, vol. 205, pp. 3975-3986. http://dx.doi.org/10.1016/j.surfcoat.2011.02.008

[5] De Groot, K., Wolke, J.G., Jansen, J.A. Calcium Phosphate Coatings for Medical Implants. Proceedings of the Institution of Mechanical Engineers. Part H, 1998, vol. 212, N 2, pp. 137-147.

[6] Xu, L., Pan, F., Yu, G., Yang, L., Zhang, E., Yang, K. In vitro and In vivo Evaluation of the Surface Bioactivity of a Calcium Phosphate Coated Magensium alloy. Biomaterials, 2009, vol. 30, N 8, pp. 1512-1523. http://dx.doi.org/10.1016/j.biomaterials.2008.12.001

[7] Thanigaiarul, K., Elayaraja, K., Magudapathy, P., et al., Surface Modification of Nanocrystalline Calcium Phosphate Bioceramic by Low Energy Nitrogen Ion Implantation. Ceramics International, 2012, http://dx.doi.org/10.1016/j.ceramint.2012.09.081
[8] Tastepe, C.S., Liu, Y., Visscher, C.M., et al. Cleaning and Modification of Intraorally Contaminated Titanium Discs with Calcium Phosphate Powder Abrasive Treatment. Clinical Oral Implants Research, 2012, http://dx.doi.org/10.1111/j.1600-0501.2012.02536.x

[9] Symietz, Ch., Lehmann, E., Gildenhaar, R., et al. Mechanical Stability of Ti6Al4V Implant Material after Femtosecond Laser Irradiation. Journal of Applied Physics, 2012, vol. 112 http://dx.doi.org/10.1063/1.4737576

[10] Hung, K.-Y., Lo, S.-Ch., Shih, Ch.-Sh., et al. Titanium Surface Modified by Hydroxyapatite Coating for Dental Implants. Surface Coating Technology, 2012. http://dx.doi.org/10.1016/j.surfcoat.2012.03.037

[11] Roohani-Esfahani, S.I., Nouri-Khorasani, S., Lu, Z.F. Modification of Porous Calcium Phosphate Surfaces with Different Geometries of Bioactive Glass Nanoparticles. Materials Science and Engineering: C, 2012, vol. 32, pp. 830-839. http://dx.doi.org/10.1016/j.msec.2012.01.034

[12] García-Gareta, E., Hua, J., Knowles, J.C., et al. Comparison of Mesenchymal Stem Cell Proliferation and Differentiation between Biomimetic and Electrochemical Coatings on Different Topographic Surfaces. Journal of Materials. Materials in Medicine, 2012, http://dx.doi.org/10.1007/s10856-012-4789-x

[13] Ohgushi, H., Dohi, Y., Tamai, S., Tabata, S. Osteogenic Differentiation of Marrow Stromal Stem Cells in Porous Hydroxyapatite Ceramics. Journal of Biomedical Materials Research, 1993, vol. 27, pp. 1401-1407. http://dx.doi.org/10.1002/jbm.820271107

[14] Oreffo, R.O.C., Driessens, F.C.M., Planell, J.A., et al. Growth and Differentiation of Human Bone Marrow Osteoprogenitors on Novel Calcium Phosphate Cements. Biomaterials, 1998, vol. 19, pp. 1845-1854. http://dx.doi.org/10.1016/S0142-9612(98)00084-2

[15] Nishio, K., Neo, M., Akiyama, H., Nishiguchi, S., et al. The Effect of Alkali and Heat treated Titanium and Apatite Formed Titanium on Osteoblastic Differentiation of Bone Marrow Cells. Journal of Biomedical Materials Research, 2000, vol. 52, N 4, pp. 652-61. http://dx.doi.org/10.1002/1097-4636(20001215)52:4<652::AIDJBM9>3.0.CO;2-W

[16] Anselme, K., Bigerelle, M., Noel, B., et al. Qualitative and Quantitative study of Human Osteoblast adhesion on Materials with Various Surface Roughnesses. Journal of Biomedical Materials Research, 2000, vol. 49, N 2, p. 155-166.

http://dx.doi.org/10.1002/(sici)1097-4636(200002)49:2<155::aidjbm2>3.0.co; $2-\mathrm{j}$

[17] Weibenbock, M., Stein, E., Undt, G., et al. Particle Size of Hydroxyapatite Granules Calcified from Red Algae Affects the Osteogenic Potential of Human Mesenchymal Stem Cells in vitro. Cells Tissues Organs, 2006, vol. 182, pp. 79-88. http://dx.doi.org/10.1159/000093062

[18] Chen, F., Lam, W.M., Lin, C.J., et al. Biocompatibility of Electrophoretical Deposition of Nanostructured Hydroxyapatite Coating on Roughen Titanium Surface: in vitro Evaluation Using Mesenchymal Stem Cells. Journal of Biomedical Materials Research, 2007, vol. 82B, pp. 183-191. http://dx.doi.org/10.1002/jbm.b.30720

[19] Kivrak, N. and Cuneyt Tas, A., Synthesis of Calcium HydroxyapatieTricalcium Phosphate (HA-TCP) Composite Bioceramic Powders and Their Sintering Behavior. Journal of American Ceramic Society, 1998, vol. 81, N 9, pp. 2245-2252. http://dx.doi.org/10.1111/j.1151-2916.1998.tb02618.x

[20] Descamps, M., Rguiti, E., Tricoteaux, A., et al. Processing and Properties of Transparent Hydroxyapatite and $\beta$-tricalcium Phosphate Obtained by HIP Pocess. Ceramics International, 2013, vol. 39, pp. 283-288. http://dx.doi.org/10.1016/j.ceramint.2012.06.023

[21] Dālmane, A., Histologìia. Rīga : LU Akadēmiskais apgāds, 2004. 319 lpp.

Vita Zalite, Mg. sc. ing. She received her Master Degree in Chemical Engineering from Riga Technical University in 2011. She is currently a doctoral student at the Department of General Chemical Engineering, Riga Technical University. In 2007, she joined the staff of Rudolfs Cimdins Riga Biomaterials Innovation and Development, Centre and since 2011 she is a Scientist. Her research interests include calcium phosphates and substituted calcium phosphates as bone and teeth regeneration materials and porous materials. V. Zalite is a coauthor of 1 patent.

E-mail: Vita.Zalite@ rtu.lv

Marina Sokolova, Bc. sc. ing. She received her Bachelor Degree in Chemical Engineering from Riga Technical University (2011), where she continues her master studies. Currently she is a Scientific Assistant at Rudolfs Cimdins Riga 
Biomaterials Innovation and Development Centre. Her research interests are related to calcium phosphate synthesis scale-up process and calcium phosphates and biodegradable polymer composite material.

E-mail: Marina.Sokolova@rtu.lv.

Dmitrijs Jakovlevs received his BS and MS degree in Chemical Engineering from Riga Technical University, Latvia. In 2010 he joined the Riga Biomaterial Innovation and Development Center of RTU as a Scientist. He is currently a doctoral student at the Department of General Chemical Engineering, Riga Technical University. His research interests include biomaterials, biomaterial microstructures, interaction between mesenchymal stem cells and biomaterials Dmitry additionally is a Specialist in SEM.

E-mail: Dmitrijs.Jakovlevs@rtu.lv

Karlis Rozenbergs graduated from the Latvia University of Agriculture, Faculty of Veterinary Medicine (1980-1997). He is a Scientific Assistant at the University of Latvia, Faculty of Biology. His work experience is associated with the Ministry of Health Food Centre of Latvia, the National Environmental Policy Plan for the development of an expert working group "Chemical Cycle of Genetically Modified Organisms and the Quality of the Products". Currently he participates in ESF project "Capacity Building for Interdisciplinary Biosafety Research". K. Rozenbergs' scientific interests are devoted to animal somatic stem cells, development of animal model for stem cell collection and isolation.

E-mail: karlis.rozenbergs@lu.lv

Liga Berzina-Cimdina, Dr. sc. ing, Professor and Head of the Institute of General Chemical Engineering and Riga Biomaterials Innovation and Development Centre. She is the Head of Department of General Chemical Engineering at RTU, Faculty of Materials Science and Applied Chemistry. She manages the study program in the following specializations: Chemistry and Technology of Biomaterials, Environmental Engineering, General Chemical Technology. Scientific research of Prof. L. Berzina-Cimdina includes the management of international and regional projects (EU, the Balkan countries, Latvia), development of new biomaterials and eco-materials, research of new applications for these materials and research on interaction of materials and biological systems. She is the author of more than 100 scientific publications, author and coauthor of 3 patents.

E-mail: liga.berzina-cimdina@rtu.lv

\section{Vita Zālīte, Marina Sokolova, Dmitrijs Jakovlevs, Kārlis Rozenbergs, Līga Bērziṇa-Cimdiṇa. Truša mezenhīmas šūnu piestiprināšanās} raksturošana uz kalcija fosfātu virsmas

Šajā darbā tika pētīta truša mezenhīmas šūnu piestiprināšanās spēja un šūnu morfolog̣ija uz dažādi apstrādātām hidroksilapatīta (HAp) un $\beta$-trikalcija fosfāta ( $\beta$-TCP) virsmām. Šāda pētījuma nozīmība saistās ar to, ka ir būtiski noskaidrot, kādai jābūt implanta virsmai, lai nodrošinātu veiksmīgu šūnu piestiprināšanos, kam vēlāk seko šūnu migrācija, proliferācija un diferenciācija. Zinātniskais darbs sevī ietver vairākas daḷas: HAp un $\beta$-TCP pulveru sintēzi un to analīzi ar rentgenstaru difraktometriju un Furjē transformāciju infrasarkano spektroskopiju, HAp un $\beta$-TCP presētu paraugu sagatavošanu un to virsmas modificēšanu, kā arī truša mezenhīmas šūnu iegūšanu, inkubēšanu un uznešanu uz HAp un $\beta$-TCP paraugiem. HAp un $\beta$-TCP presētu paraugu virsmas ar un bez šūnām tika analizētas, izmantojot skenējošo elektronu mikroskopiju. Pētījumā tika apskatīta neapstrādāta, pulēta un pulēta-termiski kodināta HAp un $\beta$-TCP keramikas virsma. Būtiskākās keramikas mikrostruktūras atškirības bija graudu izmērs, jo $\beta$-TCP keramikai ir zemāka saķepšanas sākuma temperatūra, kas noved pie lielāka graudu izmēra salīdzinājumā ar HAp keramiku, kas termiski apstrādāta $1100^{\circ} \mathrm{C}$ temperatūrā, apstrādes laiks $1 \mathrm{~h}$. Līdz ar to $\beta$-TCP keramikai ir raksturīga blīvāka mikrostruktūra. Eksperimenti ar mezenhīmas šūnām parādīja, ka tām labvēlīgāka ir neapstrādāta keramikas virsma, jo šūnu forma bija plakana un nenoteikta, kas varētu norādīt, ka šāda šūna labprātāk ,komunicēs” ar citām šūnām un sāks veidot jaunus audus. Ja šūnām ir noapalıota forma, tad paredzams, ka pēc laika tās ies bojā un jaunu audu veidošanās nenotiks. Pētījums parādīja, ka mezenhīmas šūnas labprātāk piestiprinās relatīvi raupjai materiāla virsmai gan HAp, gan $\beta$-TCP keramikas gadījumā. Iegūtais rezultāts ir labvēlīgs gadījumos, kad nepieciešams izgatavot sarežğītas formas un struktūras implantus, kuriem nav iespējama virsmas apstrāde.

Вита Залите, Марина Соколова, Дмитрий Яковлевс, Карлис Розенбергс, Лига Берзиня-Цимдыня. Характеристика закрепления мезенхимальных клеток кролика на поверхности фосфата кальция

В настоящей научной работе была изучена способность прикрепления мезенхимальных клеток кролика и морфология клеток на различных поверхностях гидроксиапатита (ГАП) и трикальцийфосфата (ТКФ). Важность такого исследования связана с тем, что необходимо знать, какой должна быть поверхность имплантата для того, чтобы обеспечить успешное прикрепление клеток для дальнейшей миграции, пролиферации и дифференциации. Научная работа включает в себя несколько частей: синтез порошков гидроксиапатита и трикальцийфосфата, их анализ методом рентгеновской дифрактометрии и инфракрасной спектроскопии Фурье, подготовка прессованных образцов и модификация их поверхности, а также получение мезенхимальных клеток кролика, их инкубация и нанесение на образцы ГАП и ТКФ. Поверхность прессованных ГАП и ТКФ образцов с клетками и без клеток была проанализирована с помощью сканирующего электронного микроскопа. В процессе исследования были рассмотрены необработанные, полированные и термически - полированные травленые ГАП и ТКФ керамические поверхности. Наиболее существенным отличием микроструктуры керамики был размер зерна, так как начальная температура спекания ТКФ керамики ниже, что приводит к большим размерам зерна по сравнению с ГАП керамикой при термообработке $1100^{\circ} \mathrm{C}(1 \mathrm{qac})$. Следовательно, ТКФ керамика характеризуется плотной микроструктурой. Эксперименты с мезенхимальными клетками показали, что самая благоприятная - это необработанная керамическая поверхность, потому что форма клеток была плоской и неопределенной, что в свою очередь означает, что такая клетка предпочтет "общаться" с другими клетками и начнет строить новую ткань. Если клетки имеют округлую форму, тогда ожидается, что со временем они будут разрушены, а образования новых тканей не произойдет. Исследования показали, что мезенхимальные клетки предпочитают цепляться к относительно грубой поверхности материала - также в случае ГАП и ТКФ керамики. Полученный результат благоприятен в случае, когда необходимо получение имплантатов сложных форм и конструкций, которые не позволяют проводить обработку поверхности. 